\title{
Rosemary Rees: actress, director, writer (1875 or 76 - 1963)
}

Sue Dunlop

Dame Ngaio Marsh, in her autobiography Black Beech and Honeydew, wrote that Rosemary Rees was probably the first person to attempt to establish a permanent theatre company in New Zealand (144). As a young woman, Ngaio Marsh was a member of this theatre company in the 1920s and may well have been inspired by it when she later established her 'Commonwealth Theatre Company' in the 1950s. Although Rosemary Rees' company did not succeed, she was an important early player in New Zealand's eventually establishing its own theatrical identity.

New Zealander Rosemary Rees is best known as a writer of popular romantic fiction. She achieved international recognition as a novelist, and published twenty-four novels between 1924 and 1962. Her work as a novelist is discussed in The Oxford History of NZ Literature in English (587-88) and in The Oxford Companion to New Zealand Literature (462), and Rees is included in the Dictionary of New Zealand Biography Volume Tour (1921-1940). However, it is less well known that her first love was theatre - acting, writing plays, and producing/directing. This essay takes a more detailed look at Rosemary Rees' early years in the theatre.

Rosemary Frances Rees was born in Auckland in either 1875 or 1876, the youngest daughter of William Lee Rees (Barrister and MP) and Annie Staite (Swarbrick, 427). She was determined from an early age to pursue a career as an actress, and to this end, she travelled to England around 1901 and joined the company of comedienne Fanny Brough. After a month on tour, she was promoted to playing leading character roles and also became Fanny Brough's understudy. At the conclusion of the tour, she was engaged by Mr Calvert Routledge to play the role of Angelica in a play called A Night Off, and then she joined

a long tour of the musical comedy $A$ Queen of Hearts in which she played lead for the first time. She gained very useful experience in a repertoire company under the management of Mr Fred Ash, playing lead in such pieces as Moths, Sorrows of Satan, Still Waters Run Deep, Our Boys, The Guvnor, The Prude's Progress, Trilby, Little Lord Fauntleroy, and The Sign of the Cross. After this she was engaged by Walter Melville for a season in London, followed by a

Kōtare 4, no. 1 (2001), pp. 32-45. 
tour of the provinces. An engagement with Mr Lewis Waller to play the Countess Souvaroff in Vihna, and Floraine in Taza followed, and she was re-engaged by Mrs Waller for her suburban tour to play principal parts. It was during this tour Mrs Waller commissioned her to revise and re-write Vihna, Miss Rees's version being played for the remainder of the tour. ${ }^{1}$

British newspaper reviews of her work from that time praise her very highly.

In 1909 she returned to New Zealand and on the $3^{\text {rd }}$ March 1909, presented an evening's entertainment billed as 'Miss Rosemary Rees: A Memorable Occasion'. The entertainment, at His Majesty's Theatre, Gisborne, included three one-act plays all of which she had written herself (a 'farcical comedy' called A Judicial Separation, a 'dramatic episode' called The New Gun, and a 'comedietta' called Her Dearest Triend), and some musical items. Rees acted in all the plays and also performed a song ('I Hid My Love') at the opening of the second half of the programme.

During her time in New Zealand she accepted work with Allan Hamilton, and was also offered work in Australia by Messrs. Meynell and Gunn but had to decline because she had already accepted Hamilton's offer.

Rosemary Rees returned to England in 1911 to further her acting career, but prior to leaving presented an evening's entertainment of three one-act plays advertised as 'Miss Rosemary Rees' Farewell Performance' at His Majesty's Theatre, Gisborne on $4^{\text {th }}$ July 1911 . The plays included a return performance of one of her own works, Her Dearest Friend. ${ }^{2}$

During the next few years in England she wrote and had produced four or five one-act plays - one play in which she also acted was produced at the Vaudeville Theatre and later at the Coliseum. At the outbreak of war, Rees was on tour in England. She played for a season in repertory and had a starring engagement as the Honorable Mrs Blain in Vachell's play 'Searchlights' before deciding to give up her own work and devote herself to the war effort (Rees, Biographical Notes, 1). She was asked by the New Zealand war contingent in London to become a member of their committee and to take on the entertainment work for the New Zealand soldiers in England. She organised concerts and entertainments and obtained theatre tickets for the soldiers from generous theatre managers (around 40,000 tickets were distributed by Rees to New Zealand soldiers), but after eighteen months of this work, her health broke down and she was ordered to rest. In recognition of her work, the New Zealand military authorities arranged a free trip for her to New Zealand in 1917. Instead of taking this trip, however, she was persuaded by Lena Ashwell, a famous

Kōtare 4, no. 1 (2001), pp. 32-45. 
English actress who was sending concert parties and dramatic parties to France, to take charge of a touring Dramatic Party which was bound for Rouen. Rees stayed with this party (the Lena Ashwell Dramatic Party) in Rouen for fourteen months from early 1918 producing and playing in a large selection of modern comedies. Their performances were often held in make-shift environments including tents, improvised stages, and small platforms in American and English hospitals. After the Armistice, the Dramatic Party headed into more war torn areas as far as Ypres in Belgium, and played for the wounded at Arras (Northern France) and for the British troops at Douai (also Northern France).

By July 1919, Rees was in a nursing home in London recovering from a breakdown due to overwork, but she maintained that the work was worth all the breakdowns.

Toward the end of that year, Rees was presented to King George at a Garden Party at Buckingham Palace, and she was obviously pleased that he was familiar with the work she had done in France and was able to talk to her at some length about it (Rees, Biographical Notes, 2).

Shortly after this royal meeting, she finally set out aboard a troop-ship for her promised trip home to New Zealand. The voyage took six weeks and although Rees was looking forward to a good rest during the trip, she ended up being put in charge of the entertainment committee. They organised dances and entertainments for the 600 troops, plus officers and wives on board, and somehow managed to keep everyone reasonably cheerful despite serious overcrowding.

Having been away from New Zealand for some years and having been overworking in very stressful environments, Rees finally enjoyed the luxury of a restful holiday during 1920. By 1921, however, tiring of having no work to do, she formed the 'Rosemary Rees English Comedy Company' to tour New Zealand. In spite of the name chosen for the company, all the performers were in fact New Zealanders. ${ }^{3}$ Members of this company included a young Ngaio Marsh, Kiore (Tor) King (a New Zealand actress who trained at the prestigious Royal Academy of Dramatic Art in London), Colleen Clifford (who later became a well-known broadcaster with the B.B.C.), George Broad, Harold Moran, Katie Towers, and a man referred to only as 'Jimmy'. There may have been others. Peter Harcourt also lists as company members: Ina Marsh (this might have been a stage name for Ngaio Marsh as she is not on Harcourt's list), Roland Stavely, George Blythe and Gregory Lamason (67).

Towards the end of the tour the company performed at the Grand Opera House, Wellington in October 1921. The main bill in Wellington was a play

Kōtare 4, no. 1 (2001), pp. 32-45. 
called The Mollusc by $\mathrm{H}$. H. Davies. ${ }^{4}$ Several details from this programme (which is reproduced at the end of the article) provide an interesting commentary on the situation of local theatre in New Zealand in the 1920s. The description of Rosemary Rees' company as an English company has already been referred to; the programme notes are even more specific, referring to Rees as an 'English Actress-authoress', and noting her splendid record 'in England and abroad'. This is clearly a marketing strategy aimed at overcoming New Zealanders' cultural cringe. In addition, the photograph of Rees on the programme cover is credited to a Sydney photographer, which may also have been a deliberate ploy to enhance the impression of an international artist touring Australasia.

On $14^{\text {th }}$ October, Rosemary Rees opened the evening's entertainment with a one-act play she wrote herself called Will You Walk Into My Parlour. A newspaper report of the time states that her play had been successful in London and New York and was being staged by request (Evening Post, 13 October, 1921, 3). The latter play was described as the story of a shady London stockbroker being outwitted by a clever actress who is the daughter of the man he is trying to ruin (Evening Post, 15 October, 1921, 9). Ngaio Marsh and Kiore King are not mentioned in the programme or newspaper reports of these performances and so presumably were not involved in either of these two productions. Peter Harcourt refers to another play, apparently written by Rees, called The Amateur Adventuress as being the play they toured (67).

Ngaio Marsh in her autobiography described Rosemary Rees' company as one of the earliest attempts to found a permanent theatre in this country, while Rees described her formation of the company as a busman's holiday (Rees, 'First Novel'). Perhaps it was Rosemary Rees' initial intention to found a permanent theatre company in New Zealand, and she later attempted to minimise the failure of the company by downplaying her initial intentions.

At that time, professional touring companies were all but a thing of the past. The huge successes of cinema and radio coupled with a fairly small population and very expensive touring costs in New Zealand meant professional touring theatre simply wasn't viable here any more. They were well received and enjoyed good reviews and good houses in the cities but could not attract audiences in the small rural centres. This was a problem which Rees put down to a severe depression caused by the London market for wool and mutton suddenly dropping, and to the attitude held in the rural centres that 'This company can't be any good or it wouldn't come here!' (Rees, 'First Novel'). They struggled on for a while believing in vain that 'one or two really good weeks

Kōtare 4, no. 1 (2001), pp. 32-45. 
would have set [them] on [their] feet again (Rees, 'First Novel')- but in the end Rees had to face the fact that she was very much in debt.

She wound up the company after three to five months ${ }^{5}$ then went to Australia to pursue her acting career. Rees said that acting work was slow in coming, that she wrote her first novel while waiting for a job, and that shortly after completing the writing of this novel, she was offered and accepted work with J.C. Williamson Ltd. to tour New Zealand ('First Novel'). Yet by January 1922, (only a couple of months after her company was performing in Wellington), Rees was reported as touring New Zealand in the J.C. Williamson production of a play called Scandal (Hawkes Bay Tribune, 24 January, 1922) playing the role of Mrs Henry Vanderdyke. This play was earlier performed at the Grand Opera House in Wellington on 16 January $1922 .^{6}$

A few months later she was rehearsing a new play in Melbourne with Lawrence Grossmith when she received a telegram advising that her first novel

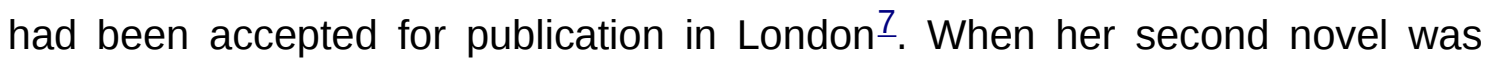
published a year later she was still working as an actress in Melbourne but sometime after that she gave up life on the stage to pursue her writing career full time. She went on to be a hugely successful writer of popular romantic fiction. By 1936, her British publisher estimated she had sold over 100,000 copies of her novels in Britain alone, and she herself maintained she was New Zealand's best-selling author.

It is possible that Rees may have made a return to the stage in the 1940s. There is a record at the National Library of a New Zealand theatre programme with her appearing in a production of Fools Rush In. Unfortunately the theatre programme is missing, and no further information has yet come to light - it may have been incorrectly dated.

Rosemary Rees, who never married, lived in London during the Second World War with her widowed sister May and the two sisters returned to New Zealand to live in Gisborne in 1955. Her last novel was published in 1962 - just one year before her death at the age of 88 on $19^{\text {th }}$ August 1963 at Chelsea Private Hospital, Gisborne.

\section{Works Cited}

- Harcourt, Peter. A Dramatic Appearance: New Zealand Theatre 1920-1970. Wellington: Methuen, 1978.

- Marsh, Ngaio. Black Beech and Honeydew. Glasgow: Fontana/Collins, 1984.

- Rees, Rosemary. "Biographical Notes." [1930] Alexander Turnbull Library, Wellington, qMS-1678.

Kōtare 4, no. 1 (2001), pp. 32-45. 
- Rees, Rosemary. "How I wrote my first novel." [c. 1971] Alexander Turnbull Library, Wellington, qMS-1679.

- Robinson, Roger and Nelson Wattie. Ed. The Oxford Companion to New Zealand Literature. Melbourne: Oxford University Press, 1998.

- Sturm, Terry. Ed. The Oxford History of New Zealand Literature in English. Auckland: Oxford University Press, 1998.

- Swarbrick, Nancy. 'Rosemary Rees.' In Dictionary of Neio Zealand Biography Volume Four (1921-1940). Auckland: Auckland University Press and Bridget Williams Books with Department of Internal Affairs, 1998.

The following pages reproduce the (slightly enlarged) theatre programme for the Wellington staging of The Mollusc. The programme was a single sheet printed on both sides and folded in three. The order of pages following attempts to re-capture the sequence in which the pages would be read.

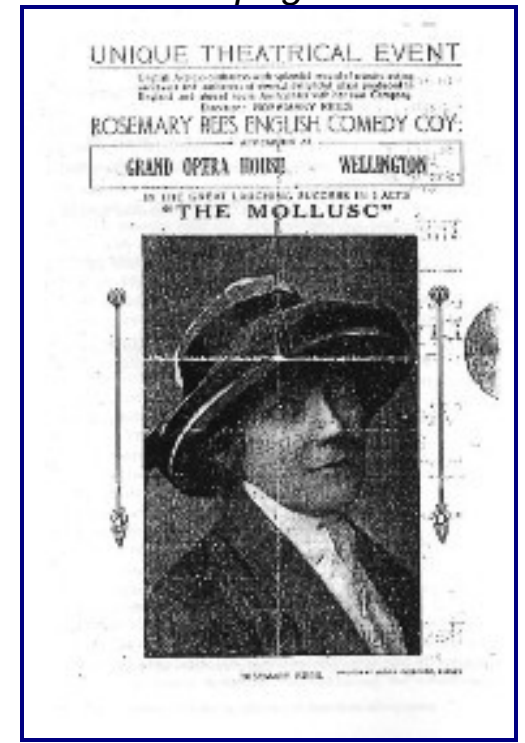

Kōtare 4, no. 1 (2001), pp. 32-45. 

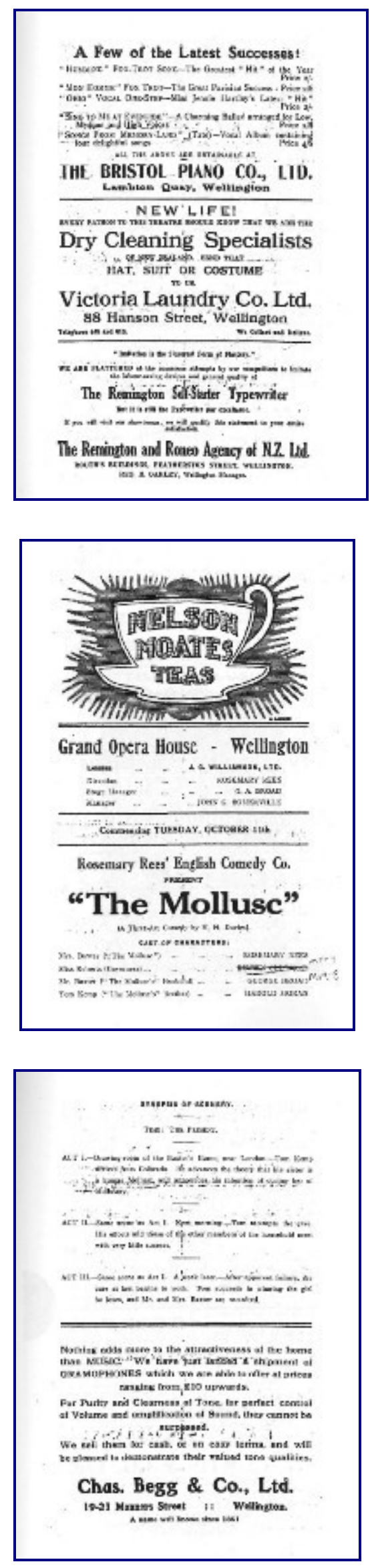

Kōtare 4, no. 1 (2001), pp. 32-45. 

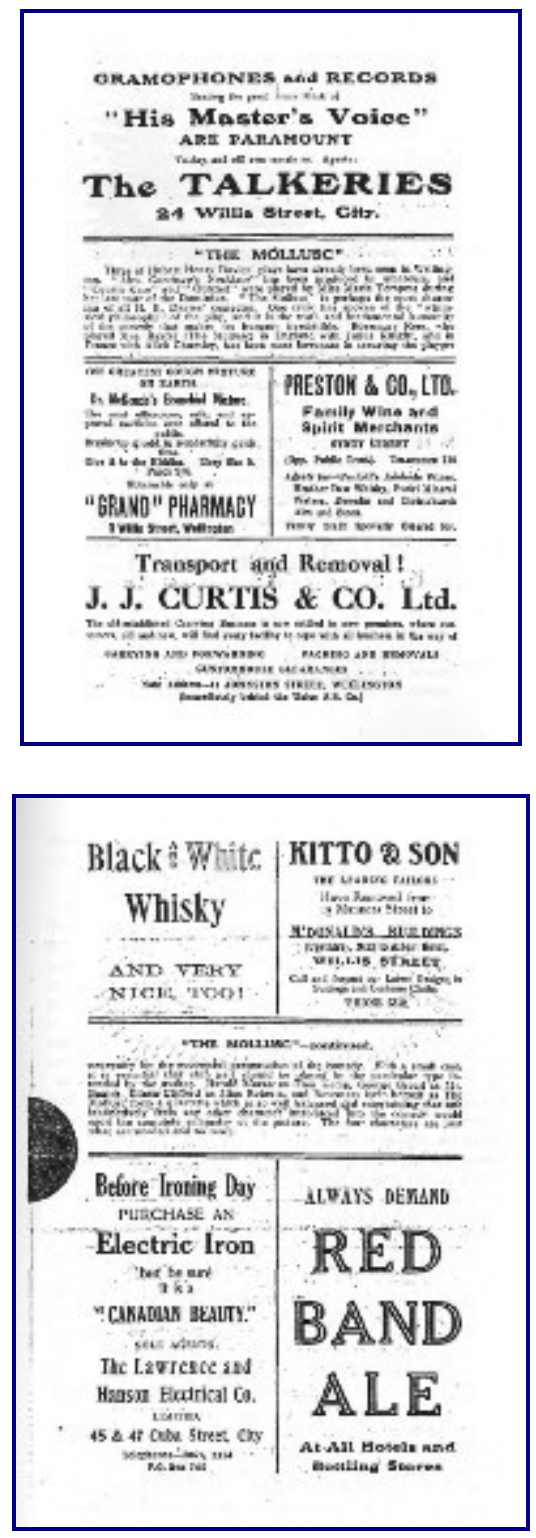

\section{Endnotes}

1 This summary is taken from the theatre programme prepared for the March 1909 entertainment 'Miss Rosemary Rees: a Memorable Occasion'. An original copy of the programme is held in the Alexander Turnbull Library's Collection of Ephemera A: Drama, 1909.

2 See the theatre programme 'Miss Rosemary Rees' Farewell Performance', Alexander Turnbull Library, Ephemera A: Drama, 1911.

3 The names of the company are drawn from Marsh's autobiography (145) and from a copy of the theatre programme for the production of The Mollusc

Kōtare 4, no. 1 (2001), pp. 32-45. 
staged at Wellington's Grand Opera House, October 1921. An original copy of the programme is held in the Peter Harcourt Collection at the Nola Miller Library, Te Whaea (New Zealand Drama School), Wellington.

4 The playwright's name is drawn from the theatre programme of the Wellington performances (see footnote 3). This evidence suggests Ngaio Marsh was incorrect in stating in her autobiography that the play they were touring was written by Rosemary Rees (144).

5 There is a minor discrepancy here between Rees' account and Ngaio Marsh's account of the duration of the tour. Marsh (146) states the tour survived three months while Rees ('Biographical Notes', 3) says five months. Unfortunately neither give start or finish dates of the tour.

6 A programme of the Wellington season of this play is also held in the Ephemera section of the holdings of the Alexander Turnbull Library.

7 Her first novel was later also syndicated in American newspapers. 